\title{
Phytoextraction Efficiency of Lead by Arum (Colocasia esculenta L.) Grown in Hydroponics
}

\author{
Md. Shoffikul Islam*, Md. Abul Kashem, Khan Towhid Osman \\ Department of Soil Science, University of Chittagong, Chittagong, Bangladesh \\ Email: *msislam@cu.ac.bd, "bipul_pirob@yahoo.com
}

Received 9 June 2016; accepted 12 July 2016; published 21 July 2016

Copyright (C) 2016 by authors and Scientific Research Publishing Inc.

This work is licensed under the Creative Commons Attribution International License (CC BY). http://creativecommons.org/licenses/by/4.0/

(c) (i) Open Access

\begin{abstract}
Lead (Pb) tolerance and phytoextraction efficiency of arum (Pani Kachu; Colocasia esculenta L.) were investigated in hydroponics. Plants were grown for 60 days in nutrient solution after addition of $\mathrm{Pb}$ at the levels of $0,50,200$ and $400 \mu \mathrm{M}$. The growth of different parts of arum was unaffected at low level of $\mathrm{Pb}$ concentration $(50 \mu \mathrm{M} \mathrm{Pb})$ compared with control treatment whereas it decreased gradually with the increase of metal concentration in nutrient solution. Concentration of metal in all parts of arum increased significantly with the levels of $\mathrm{Pb}$ in the growth media $(p<$ 0.05). In arum shoots, $\mathrm{Pb}$ concentration was $1121 \mathrm{mg} \cdot \mathrm{kg}^{-1}$, at its low level in solution. This concentration $(50 \mu \mathrm{M} \mathrm{Pb})$ did not cause any growth retardation which indicated that arum was a $\mathrm{Pb}$ hyperaccumulator plant. On an average, translocation of $\mathrm{Pb}$ from roots to shoots was $68 \%$ of total $\mathrm{Pb}$ which indicated that the major portion of $\mathrm{Pb}$ was translocated from roots to shoots. Transfer factor (TF) greater than one for this metal as found in the present experiment confirmed the hyperaccumulation characteristics of arum. Lead uptake in the shoots of arum without growth retardation and TF of $\mathrm{Pb}$ in arum indicated that this plant was a suitable candidate for the phytoremediation of soil and water contaminated with $P b$.
\end{abstract}

\section{Keywords}

Water, Contamination, Metal, Hyperaccumulator, Toxicity

\section{Introduction}

Environmental pollution by heavy metals, even if it is at low concentrations and the long-term cumulative health

\footnotetext{
"Corresponding author.
}

How to cite this paper: Islam, M.S., Kashem, M.A. and Osman, K.T. (2016) Phytoextraction Efficiency of Lead by Arum (Colocasia esculenta L.) Grown in Hydroponics. Open Journal of Soil Science, 6, 113-119. 
effects that go with it, are of major health concerns all over the world [1]. Heavy metals occur naturally in the ecosystem with large variations in concentrations. In modern times, anthropogenic sources of heavy metals, i.e. pollutions from the activities of humans, have introduced some of these heavy metals into the ecosystem [1]. In Bangladesh, industrial wastes and effluents are commonly discharged onto agricultural lands, into canals and rivers, and along road sides or in the vicinity of industrial operations without any primary or secondary treatment. As a result, they are major pollutants of productive soils, natural water systems and ground water and have created an extremely serious contamination problem in Bangladesh [2].

Among the heavy metals, $\mathrm{Pb}$ belongs to those elements that are poorly mobile and rarely available to plants. However, it may create different organic and inorganic compounds that are easily absorbed by plants roots and thus posse's health risk on human through the food chain [3]. Lead concentrations in some industrial sites of Bangladesh are found to range from $17-99 \mathrm{mg} \cdot \mathrm{kg}^{-1}$ [4] which are above the background level for $\mathrm{Pb}$ in soil (12 - $20 \mathrm{mg} \cdot \mathrm{kg}^{-1}$ ) [5]. However, the concentrations of $\mathrm{Pb}$ in vegetables grown in Bangladesh are observed in the range of $10-26 \mathrm{mg} \cdot \mathrm{kg}^{-1}$ dry weight by Ahmad and Gani [6] and $13-45 \mathrm{mg} \cdot \mathrm{kg}^{-1}$ dry weight by Kashem and Singh [4]. These values exceed the acceptable tolerance level for FAO/WHO standard of $5 \mathrm{mg} \cdot \mathrm{Pb}^{\circ} \mathrm{kg}^{-1} \mathrm{dry}$ weight [7] and of $10-20 \mathrm{mg} \cdot \mathrm{Pb} \mathrm{kg}^{-1}$ dry weight recommended by Sauerbeck [8]. There is an urgent need to develop methods to cleanup metals especially $\mathrm{Pb}$ in contaminated soils. Most traditional remediation techniques are physical or chemical that involves high cost and has low public acceptance [9]. In recent years, phytoremediation, where hyperaccumulators or accumulators are used to take up large quantities of pollutants, has become a promising remediation technique, for it is both environmentally sound and cost effective [10]. To date, there are more than 400 plant species known to hyperaccumulate heavy metals, of which only few have been considered as $\mathrm{Pb}$ hyperaccumulators [11], and most of them have not been widely used because of low biomass production, difficulty in cultivation and slow growth rates [12]. Some metal accumulators such as Thlaspi caerulescens [13] [14], Arabidopsis halleri gemmifera [2] [15] and Sedum alfredii hance [16] have been reported to have substantial potential for phytoextraction at low cost for soil metal remediation. However, these metal accumulators may not always be suitable for large scale remediation efforts because the plants are small, grow slowly and produce very low biomass. In the present investigation, we select a common and locally popular plant species arum (Pani Kachu; Colocasia esculenta L.). This plant is widely distributed in Bangladesh and can grow in both dry and marshy conditions. It has deep roots and long shoots. It possesses the characteristics of high biomass, easy cultivation, extensive competitive ability and strong resistance to environmental stresses. Kashem et al. [17] conducted a hydroponics experiment in Japan with a different arum species (Colocasia antiqourum L.) and found that this plant had strong tolerance to $\mathrm{Cd}$ in the nutrient solution and strong accumulation capability of $\mathrm{Cd}$ in its body. Although there are few research on phytoextraction of $\mathrm{Pb}$ by some species [18] [19] but till date, there is no research to investigate the $\mathrm{Pb}$ tolerance and phytoextraction efficiency of arum species of $C$. esculenta $\mathrm{L}$. neither in hydroponics nor in soil cultures. Hydroponics provides potential to examine metal tolerance and magnitude of metal accumulation in plant species with greater precision than soil studies. In the present paper, $\mathrm{Pb}$ tolerance and phytoextraction efficiency of arum grown in nutrient solution containing different levels of $\mathrm{Pb}$ were studied.

\section{Materials and Methods}

The experiment was carried out in the net house of the Department of Soil Science of the University of Chittagong, Bangladesh under natural light conditions. Healthy and uniform size plantlets of arum (Colocasia esculenta L.) were collected from the agricultural field near the University of Chittagong Campus. The plantlets were tightly set in the holes in the central position of plastic covers using foam and were placed above the 15-L plastic pots containing 10-L half-strength nutrient solution. The composition of half-strength modified Hoagland-Arnon [20] nutrient solution (standard solution) was: $3.0 \mathrm{mM} \mathrm{KNO}{ }_{3} ; 2.0 \mathrm{mM} \mathrm{Ca}\left(\mathrm{NO}_{3}\right)_{2} ; 0.5 \mathrm{mM}$ $\mathrm{NH}_{4} \mathrm{H}_{2} \mathrm{PO}_{4} ; 1.0 \mathrm{mM} \mathrm{MgSO}_{4} ; 10 \mu \mathrm{M}$ Fe-EDTA; $1.5 \mu \mathrm{M} \mathrm{H}_{3} \mathrm{BO}_{3} ; 0.25 \mu \mathrm{M} \mathrm{MnSO}_{4} ; 0.1 \mu \mathrm{M} \mathrm{CuSO}_{4} ; 0.2 \mu \mathrm{M}$ $\mathrm{ZnSO}_{4}$; and $0.025 \mu \mathrm{M} \mathrm{H}_{2} \mathrm{MoO}_{4}$. Two weeks after transplanting, $\mathrm{Pb}$ at the levels of $0,50,200$ and $400 \mu \mathrm{M}$ as $\mathrm{Pb}\left(\mathrm{NO}_{3}\right)_{2}$ (ACS Grade, Sigma-Aldrich Co.) was added to the half-strength nutrient solution according to Tanhan et al. [19] and Liu et al. [21]. There were three replicates of each treatment and each replicate consisted of one plantlet. The level of the solution was maintained by adding deionized water and renewing once every 7 days. The $\mathrm{pH}$ level of the solutions was adjusted to 5.5 daily either with $1 \mathrm{M} \mathrm{NaOH}$ or $1 \mathrm{M} \mathrm{HCl}$ using a digital $\mathrm{pH}$ meter. 
Plants were harvested 60 days after addition of $\mathrm{Pb}$ in nutrient solution. Plants were then washed with tap water and then deionized water. The fresh weight of plants was measured. Then the plants were separated into dead leaves, normal leaves, stems, rhizomes and roots. All plant parts were oven dried at $68^{\circ} \mathrm{C}$ for $72 \mathrm{~h}$. After measuring their dry weights, the plant parts were grounded using a stainless steel grinder (Black \& Decker BX3600-B5 Blender with Grinder \& Chopper-300 Watt). The plants parts were digested with $\mathrm{HNO}_{3}-\mathrm{HClO}_{4}(3: 1)$ mixture [22]. Around $0.5 \mathrm{~g}$ of plant samples were taken in digestion tube. Almost 20 times $\mathrm{HNO}_{3}$ was added for each sample and was heated at $100^{\circ} \mathrm{C}$ continuously for 10 hours on digestion block. After cooling (overnight 7 hours), additional $5 \mathrm{~mL} \mathrm{HNO}_{3}$ was added and again heated for 11 hours at $140^{\circ} \mathrm{C}$ for 7 hours. After cooling (overnight 7 hours), $5 \mathrm{~mL} \mathrm{HClO}_{4}$ was added and again heated for 11 hours at $140^{\circ} \mathrm{C}$. Then the digested samples were cooled and were volume in $50 \mathrm{~mL}$ volumetric flask and stored in $50 \mathrm{~mL}$ acid washed plastic bottle. Lead in the digests was measured using atomic absorption spectrophotometer (Agilent Technologies, 420 AA, Australia). Reagent blanks were processed to ensure $\mathrm{Pb}$ was not added during sample preparation. The transfer factor (TF) is the ratio of metal concentration in shoots to those in roots of plant [23]. The TF of $\mathrm{Pb}$ was measured by dividing the concentration of this metal in shoots to those in roots of arum grown in nutrient solution. All results are presented on dry weight (DW) basis.

The results obtained were subjected to one way analysis of variance using Minitab Program [24].

\section{Results}

\subsection{Effects of Pb on Plant Growth}

There were no visible symptoms of toxicity and growth reduction in any part of arum at low $\mathrm{Pb}$ treatment (50 $\mu \mathrm{M})$, but the growth of the plant was decreased significantly $(p<0.05)$ at the highest Pb treatments $(400 \mu \mathrm{M})$. The dry weight of arum at $50 \mu \mathrm{M} \mathrm{Pb}$ were 3.2, 34.4, 58, 44.5 and $14.4 \mathrm{~g}$ for the dead leaves, normal leaves, stems, rhizomes and roots, respectively, while at $400 \mu \mathrm{M}$ the corresponding values were 1.6, 21.4, 30.1, 27 and $13.5 \mathrm{~g}$ (Figure 1).

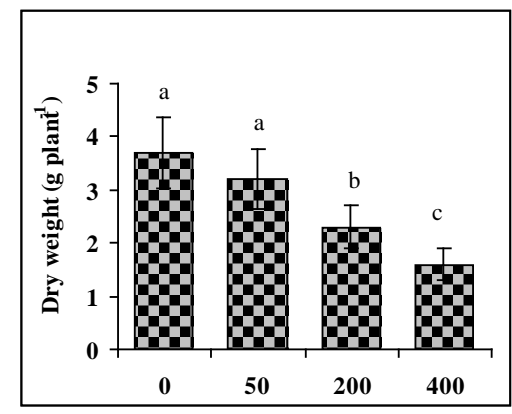

(a)

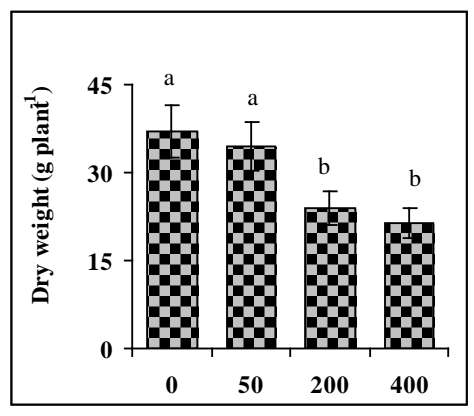

(b)

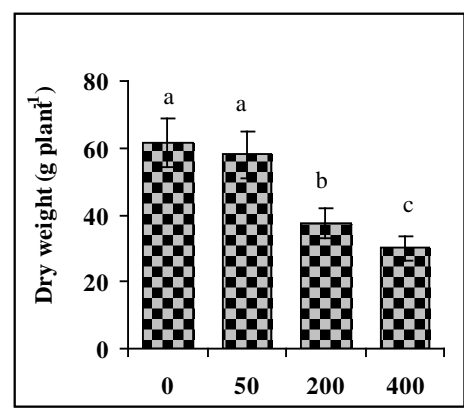

(c)
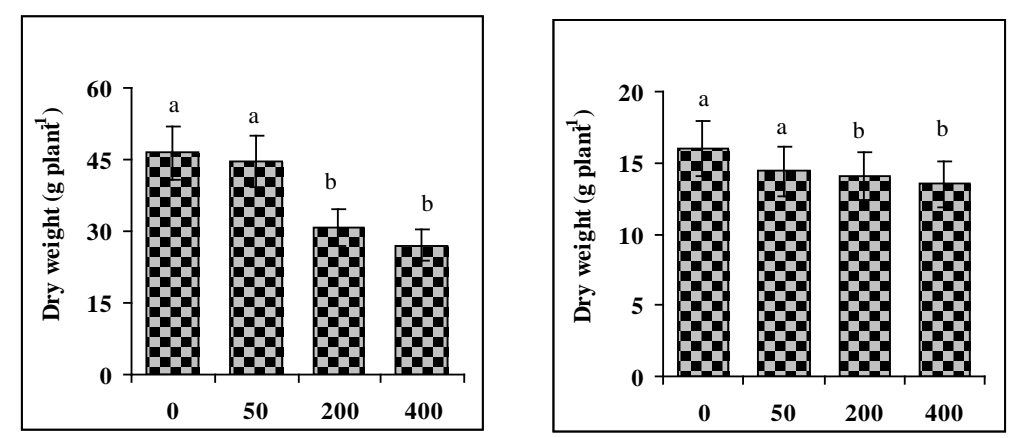

Rate of $\mathrm{Pb}(\boldsymbol{\mu M})$

(d)

(e)

Figure 1. Dry weight of arum plant parts (a) Dead Leaves; (b) Normal Leaves; (c) Stems; (d) Rhizomes; (e) Roots. Bars with the same letters within the plant parts are not significantly different from each other at $p<0.05$. 


\subsection{Lead Concentrations and Its Accumulations in Arum Plant}

The concentrations of $\mathrm{Pb}$ in different parts of arum increased significantly $(p<0.05)$ with increasing its levels in the nutrient solution. In control treatment, concentrations of $\mathrm{Pb}$ could not be detected in plant parts and were not shown in table and figures. Lead concentrations increased from 406 to $8266 \mathrm{mg} \cdot \mathrm{kg}^{-1}$ in the dead leaves, 273 to $3999 \mathrm{mg} \cdot \mathrm{kg}^{-1}$ in the normal leaves, 442 to $7004 \mathrm{mg} \cdot \mathrm{kg}^{-1}$ in the stems, 49 to $807 \mathrm{mg} \cdot \mathrm{kg}^{-1}$ in the rhizomes and 1062 to $9014 \mathrm{mg} \cdot \mathrm{kg}^{-1}$ in the roots when Pb concentration in the nutrient solution increased from 50 to $400 \mu \mathrm{M}$ $\mathrm{Pb}$. In the whole plant, $\mathrm{Pb}$ concentration was 348, 2222 and $4839 \mathrm{mg} \cdot \mathrm{kg}^{-1}$, respectively at solution $\mathrm{Pb}$ levels of 50, 200 and $400 \mu \mathrm{M}$ (Figure 2).

Similar to $\mathrm{Pb}$ concentrations, the accumulations of $\mathrm{Pb}$ based on concentration and dry weight of plant significantly $(p<0.05)$ increased in different parts of plant with the $\mathrm{Pb}$ application rates applied in nutrient solution. At the lowest rate of $\mathrm{Pb}$ application $(50 \mu \mathrm{M}), \mathrm{Pb}$ accumulations were 1, 9, 26, 2 and $15 \mathrm{mg}$ plant $^{-1}$ in the dead leaves, normal leaves, stems, rhizomes and roots, respectively and the corresponding values at the highest $\mathrm{Pb}$

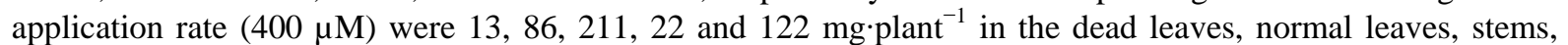
rhizomes and roots, respectively. However, accumulation of $\mathrm{Pb}$ in the whole plant was 53, 242 and 454 $\mathrm{mg} \cdot \mathrm{plant}^{-1}$ at $\mathrm{Pb}$ levels in the solution were 50, 200 and $400 \mu \mathrm{M}$, respectively. Lead accumulations in different parts of plant decreased in the order: stems $>$ roots $>$ normal leaves $>$ rhizomes $>$ dead leaves (Figure 3 ).

\subsection{Distribution and TF of $\mathrm{Pb}$ in Arum Plant}

Lead distribution (percent of the total uptake) of arum did not very significantly in the plant parts with $\mathrm{Pb}$ application rates except in the rhizomes, where it increased from $4 \%$ to $5 \%$ when the $\mathrm{Pb}$ application rates increased from 50 to $400 \mu \mathrm{M}$. On an average, about $68 \%$ and $28 \%$ of the total $\mathrm{Pb}$ were found in the shoots (leaves plus stems) and in the roots of arum which indicated that the major portions of the metal were translocated from roots to shoots irrespective of its application rates in the nutrient solution (Table 1).

The TF values of $\mathrm{Pb}$ increased with its application rates in solution. The TF values for $\mathrm{Pb}$ ranged from 1.1 to 2.1 in the metal added treatments (Table 1 ).

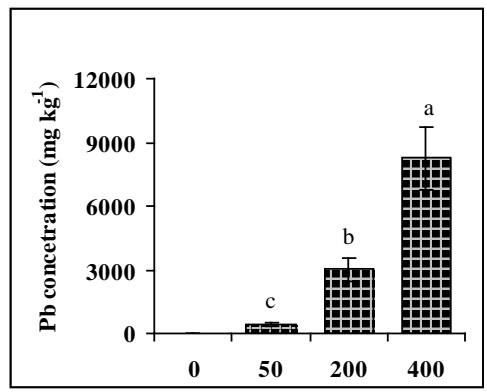

(a)

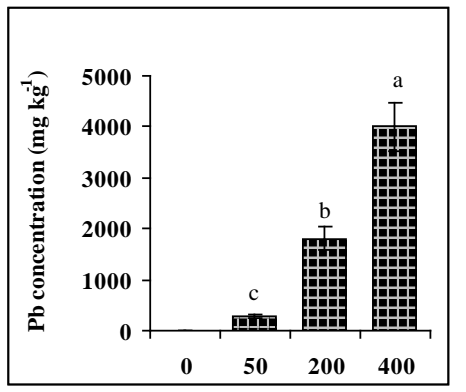

(b)

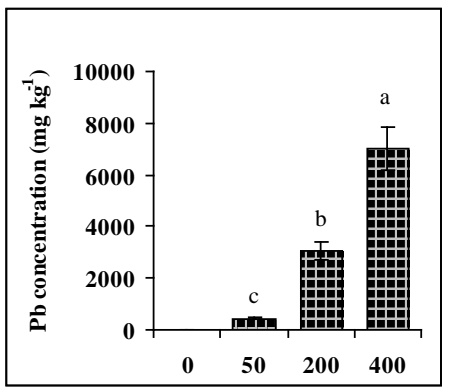

(c)
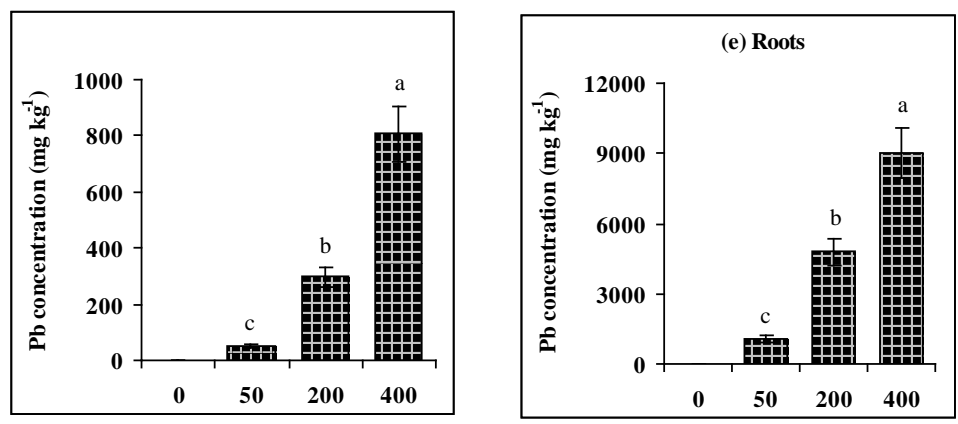

Pb Concentration $(\mu \mathrm{M})$

(d)

(e)

Figure 2. Lead concentration in arum plant parts (a) Dead Leaves; (b) Normal Leaves; (c) Stems; (d) Rhizomes; (e) Roots. Bars with the same letters within the plant parts are not significantly different from each other at $p<0.05$. 


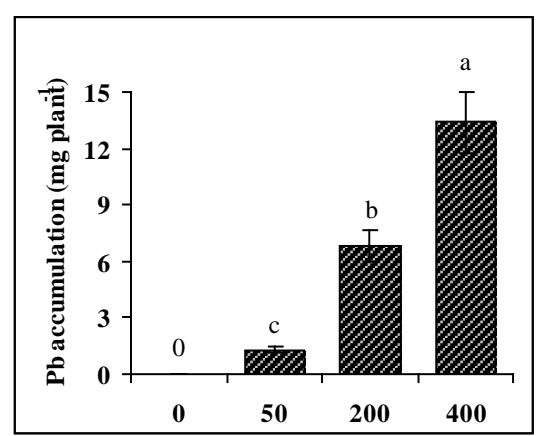

(a)

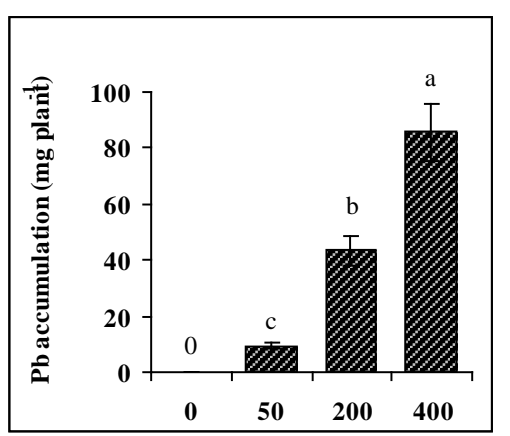

(b)

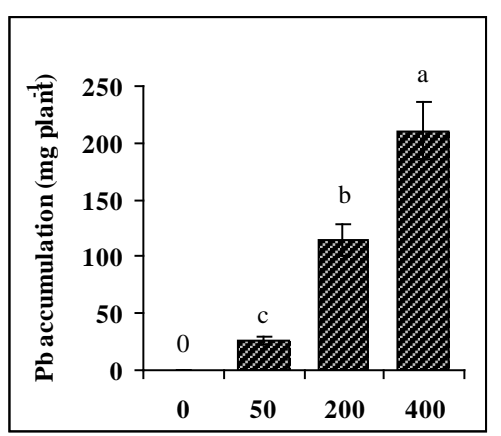

(c)
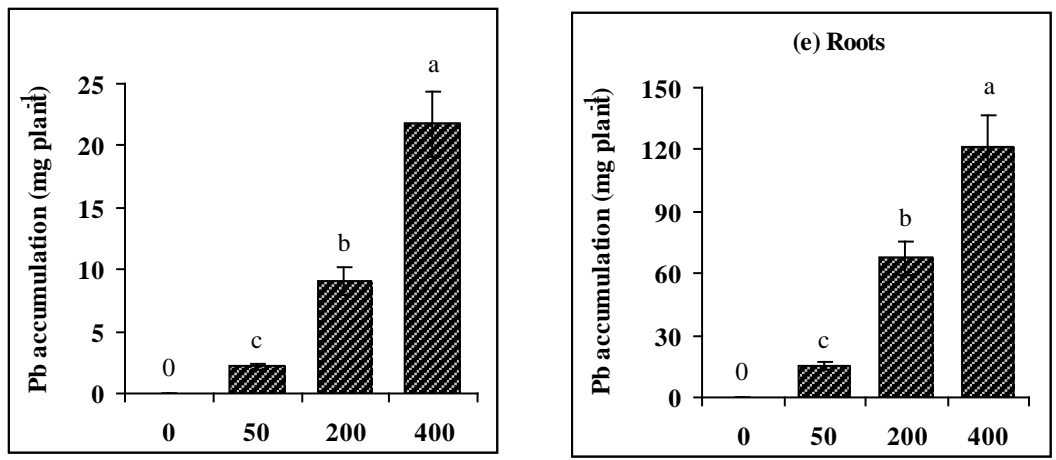

Pb accumulation ( $\mu \mathrm{M})$

(d)

(e)

Figure 3. Lead accumulation in arum plant parts (a) Dead Leaves; (b) Normal Leaves; (c) Stems; (d) Rhizomes; (e) Roots. Bars with the same letters within the plant parts are not significantly different from each other at $p<0.05$.

Table 1. Effect of $\mathrm{Pb}$ application on the $\mathrm{Pb}$ distribution and $\mathrm{TF}$ of arum plant grown in hydroponics.

\begin{tabular}{cccccccc}
\hline \multirow{2}{*}{$\begin{array}{c}\text { Treatment } \\
\mathrm{Pb}(\mu \mathrm{M})\end{array}$} & \multicolumn{9}{c}{ Pb distribution (\%) } & TF \\
\cline { 2 - 6 } & Dead Leaves & Normal Leaves & Stems & Rhizomes & Roots & nd \\
\hline 0 & nd & nd & nd & nd & nd & 0 \\
50 & $2.4 \pm 0.03 \mathrm{a}$ & $17.5 \pm 0.32 \mathrm{a}$ & $47.6 \pm 0.35 \mathrm{a}$ & $4.1 \pm 0.12 \mathrm{~b}$ & $28.4 \pm 0.71 \mathrm{a}$ & 1.1 \\
200 & $2.8 \pm 0.05 \mathrm{a}$ & $18.0 \pm 0.46 \mathrm{a}$ & $47.4 \pm 0.63 \mathrm{a}$ & $3.8 \pm 0.11 \mathrm{~b}$ & $28.0 \pm 0.71 \mathrm{a}$ & 1.6 \\
400 & $3.0 \pm 0.41 \mathrm{a}$ & $18.9 \pm 0.39 \mathrm{a}$ & $46.5 \pm 0.41 \mathrm{a}$ & $4.8 \pm 0.22 \mathrm{a}$ & $26.8 \pm 0.47 \mathrm{a}$ & 2.1 \\
\hline
\end{tabular}

Means with the same letter in each column within the parameter are not significantly different at $p<0.05$.

\section{Discussion}

There are three indicators to define a plant as $\mathrm{Pb}$ hyperaccumulator: (1) the concentrations of $\mathrm{Pb}$ in plant shoots > $1000 \mathrm{mg} \cdot \mathrm{kg}^{-1}$ [25]; (2) the concentration of $\mathrm{Pb}$ in shoots is 10 - 500 times more than that in plants from non-polluted areas ( $\mathrm{Pb} 5 \mathrm{mg} \cdot \mathrm{kg}^{-1}$ ) [26] and (3) The TF $>1$ [23] [25]. In the present study C. esculenta L. could be considered as a $\mathrm{Pb}$ hyperaccumulator according to all three indicators. It showed that this plant had high $\mathrm{Pb}$ concentration in its shoots $\left(1121 \mathrm{mg} \cdot \mathrm{kg}^{-1}\right)$ and a TF $>1$. A higher TF in plant is important in practical phytoremediation of heavy metal contaminated soil because it enables phytoremediation by harvesting only the above ground parts of plants [27]. The TF in all confirmed hyperaccumulator are therefore above one, whereas they are invariably below unity in nonacccumulators [19].

Scientists are always searching new plants for the purpose of phytoremediation. There are several studied reported on $\mathrm{Pb}$ hyperaccumulation by various plant species. It showed that Brassica pekinesis accumulate 3688 and $10028 \mathrm{mg} \cdot \mathrm{kg}^{-1}$ of $\mathrm{Pb}$ in its shoots at 500 and $1000 \mu \mathrm{g} \cdot \mathrm{ml}^{-1}$ of $\mathrm{Pb}$, respectively [18]. Sesbania drummondii 
could also accumulate $>4000 \mathrm{mg} \cdot \mathrm{kg}^{-1}$ of $\mathrm{Pb}$ in its shoots when treated with $1000 \mathrm{mg} \cdot \mathrm{L}^{-1} \mathrm{~Pb}$ [19]. In comparison to these, $C$ esculenta $\mathrm{L}$. can be classified as a good hyperaccumulator as this plant could accumulate 1121 $\mathrm{mg} \cdot \mathrm{kg}^{-1}$ of $\mathrm{Pb}$ without growth retardation when treated with as low as $50 \mu \mathrm{M} \mathrm{Pb}\left(10.4 \mathrm{mg} \cdot \mathrm{L}^{-1} \mathrm{~Pb}\right)$.

It is important to select a phytoextraction plant with high metal accuumulation capability and is also compatible with mechanized cultivation practice and local weather conditions. However, it is unfortunate that some of the best hyperaccumulator are relatively small in size, grow very slowly and making it difficult to harvest them mechanically and limiting the metal extraction that can be achieved [28]. In the present study C. esculenta L. with many roots can absorb and accumulate substantial amounts of $\mathrm{Pb}$ and it is possible to harvest the entire plant including roots. It is fast growing, easily propagated, easy to manage and capable of growing in both dry and marshy conditions. This plant appears to possess the potential to provide a novel technique for the remediation of $\mathrm{Pb}$ in contaminated soil and water.

\section{Conclusion}

The results of this study indicate that the growth of arum is unaffected by application of low level of $\mathrm{Pb}$ in nutrient solution. The concentrations of this metal found in shoot tissue and the TF of this metal in arum plant indicate that this plant has an excellent potential for $\mathrm{Pb}$ phytoextraction. If plant uptake under field soil conditions is similar to that observed in this experiment, then this plant can be used to decontaminate soil moderately contaminated with $\mathrm{Pb}$. Future studies need to be conducted with different types of arum species in both hydroponics and soil media.

\section{References}

[1] Opaluwa, O.D., Aremu, M.O., Ogbo, L.O., Abiola, K.A., Odiba, I.E., Abubakar, M.M. and Nweze, N.O. (2012) Heavy Metal Concentrations in Soils, Plant Leaves and Crops Grown around Dump Sites in Lafia Metropolis, Nasarawa State, Nigeria. Advances in Applied Science Research, 3, 780-784.

[2] Kashem, M.A., Singh, B.R., Kubota, H., Nagashima, R.S., Kitajima, N. and Kondo, T. (2007) Assessing the Potential of Arabidopsis halleri ssp. gemmifera as a New Cadmium Hyperaccumulator Grown in Hydroponics. Canadian Journal of Soil Science, 87, 499-502.

[3] Wang, Q.R., Cui, Y.S., Liu, X.M., Dong, Y.T. and Christie, P. (2003) Soil Contamination and Plant Uptake of Heavy Metals at Polluted Sites in China. Journal of Environmental Science and Health. Part A, Toxic/Hazardous Substances and Environmental Engineering, 38, 823-838. http://dx.doi.org/10.1081/ESE-120018594

[4] Kashem, M.A. and Singh, B.R. (1999) Heavy Metal Contamination of Soil and Vegetation in the Vicinity of Industries in Bangladesh. Water, Air, and Soil Pollution, 115, 347-361. http://dx.doi.org/10.1023/A:1005193207319

[5] Singh, B.R. and Steinnes, E. (1994) Soil Processes and Water Quality, Lewis Publishers, Chelsea, 233-271.

[6] Ahmad, J.U. and Goni, M.A. (2010) Heavy Metal Contamination in Water, Soil, and Vegetables of the Industrial Areas in Dhaka, Bangladesh. Environmental Monitoring and Assessment, 166, 347-357. http://dx.doi.org/10.1007/s10661-009-1006-6

[7] Codex Alimentarious Commission (1984) Contaminants, Joint FAO/WHO Food standards Program. Vol. XVII, 1st Edition, Codex Alimentarious, Geneva.

[8] Sauerbeck, D. (1982) Welche Schwermetallgehalte in Pflanzen dürfen nicht überschritten werden, um Wachstumsbeeinträchtigungen zu vermeiden? Landw. Forsch. Sonderheft, Kongressband, 39, 108-129.

[9] Prabha, K.P. and Loretta, Y.L. (2007) Phytoremediation Technology: Hyperaccumulation Metals in Plants. Water, Air, and Soil Pollution, 184, 105-126. http://dx.doi.org/10.1007/s11270-007-9401-5

[10] Han, Y.L., Yuan, H.Y., Huang, S.Z., Guo, Z., Xia, B. and Gu, J.G. (2007) Cadmium Tolerance and Accumulation by Two Species of Iris. Ecotoxicology, 16, 557-563. http://dx.doi.org/10.1007/s10646-007-0162-0

[11] Wei, S.H., Zhou, Q.X. and Wang, X. (2005) Cadmium-Hyperaccumulator Solanum nigrum L. and Its Accumulating Characteristics. Journal of Environmental Sciences, 26, 167-171.

[12] Zhou, Y.Q., Huang, S.Z., Yu, S.L., Gu, J.G., Zhao, J.Z., Han, Y.L. and Fu, J.J. (2010) The Physiological Response and Sub-Cellular Localization of Lead and Cadmium in Iris pseudacorus L. Ecotoxicology, 19, 69-76. http://dx.doi.org/10.1007/s10646-009-0389-z

[13] Lombi, E., Zhao, F.J., Dunham, S.J. and McGrath, S.P. (2000) Cadmium Accumulation in Populations of Thlaspi caerulescens and Thlaspi goesingense. New Phytologist, 145, 11-20. http://dx.doi.org/10.1046/j.1469-8137.2000.00560.x

[14] Chaney, R.L., Reeves, P.G., Ryan, J.A., Simmons, R.W., Welch, R.M. and Angle, J.S. (2004) An Improve Under- 
standing of Soils Cd Risks to Humans and Low Costs Methods to Phytoextract Cd from Contaminated Soils to Prevent Soil Cd Risks. BioMetals, 17, 549-553. http://dx.doi.org/10.1023/B:BIOM.0000045737.85738.cf

[15] Kubota, H. and Takenaka, C. (2003) Arabis gemmifera Is a Hyperaccumulator of Cd and Zn. International Journal of Phytoremediation, 5, 197-201. http://dx.doi.org/10.1080/713779219

[16] Yang, X.E., Li, T.Q., Long, X.X., Xiong, Y.H., He, Z.L. and Stoffella, P.J. (2006) Dynamics of Zinc Uptake and Accumulation in the Hyperaccumulating and Non-Hyperaccumulating Ecotypes of Sedum alfredii hance. Plant and Soil, 284, 109-119. http://dx.doi.org/10.1007/s11104-006-0033-0

[17] Kashem, M.A., Singh, B.R., Huq, S.M.I. and Kawai, S. (2008) Cadmium Phytoextraction Efficiency of Arum (Colocasia antiqourum), Radish (Raphanus sativus L.) and Water Spinach (Ipomoea aquatica) Grown in Hydroponics. Water, Air, and Soil Pollution, 192, 273-279. http://dx.doi.org/10.1007/s11270-008-9654-7

[18] Xion, Z.T. (1998) Lead Uptake and Effects on Seed Germination and Plant Growth in a Pb Hyperaccumulator Brassica Pekinensis Rupr. Bulletin of Environmental Contamination and Toxicology, 60, 285-291. http://dx.doi.org/10.1007/s001289900623

[19] Tanhan, P., Kruatrachue, M., Pokethitiyook, P. and Chaiyarat, R. (2007) Uptake and Accumulation of Cadmium, Lead and Zinc by Siam Weed [Chromolaena odorata (L.) King \& Robinson]. Chemosphere, 68, 323-329. http://dx.doi.org/10.1016/j.chemosphere.2006.12.064

[20] Hoagland, D.R. and Arnon, D.I. (1950) The Water-Culture Method for Growing Plants without Soil. Agricultural Experimental Station/University of California, Berkeley.

[21] Liu, D., Li, S., Islam, E., Chen, J.R., Wu, J.S., Ye, Z.Q., Pengi, D.L., Yani, W.B. and Lu, K.P. (2015) Lead Accumulation and Tolerance of Moso Bamboo (Phyllostachys pubescens) Seedlings: Applications of Phytoremediation. Journal of Zhejiang University-Science B (Biomedicine \& Biotechnology), 16, 123-130. http://dx.doi.org/10.1631/jzus.B1400107

[22] Piper, C.S. (1942) Soil and Plant Analysis. Hassell Press, Adelaide.

[23] Baker, A.J.M., McGrath, S.P., Sidoli, C.M.D. and Reeves, R.D. (1994) The Possibility of in Situ Heavy Metal Decontamination of Polluted Soils Using Crops of Metal Accumulating Plants. Resources, Conservation and Recycling, 11, 41-49. http://dx.doi.org/10.1016/0921-3449(94)90077-9

[24] Minitab Inc (1996) Minitab User Guide Release 11. State College, PA.

[25] Baker, A.J.M. and Brooks, R.R. (1989) Terrestrial Higher Plants which Hyperaccumulate Metallic Elements-A Review of Their Distribution, Ecology and Phytochemistry. Biorecovery, 1, 81-126.

[26] Shen, Z.G. and Liu, Y.L. (1998) Progress in the Study of the Plants That Hyperaccumulate Heavy Metals. Plant Physiology Communications, 34, 133-139.

[27] Nanda-Kumar, P.B.A., Dushenkov, V., Motto, H. and Raskin, I. (1995) Phytoextraction: The Use of Plants to Remove Heavy Metals from Soils. Environmental Science and Technology, 29, 1232-1238. http://dx.doi.org/10.1021/es00005a014

[28] Xu, S.G., Chen, Y.X., Reevs, R.D., Baker, A.J.M., Lin, Q. and Fernando, D.R. (2004) Manganese Uptake and Accumulation by the Hyperaccumulator Plant Phytolacca acinosa Roxb. (Phytolaccaceae). Environmental Pollution, 131, 393-399. http://dx.doi.org/10.1016/j.envpol.2004.03.011

\section{Submit or recommend next manuscript to SCIRP and we will provide best service for you:}

Accepting pre-submission inquiries through Email, Facebook, Linkedin, Twitter, etc

A wide selection of journals (inclusive of 9 subjects, more than 200 journals)

Providing a 24-hour high-quality service

User-friendly online submission system

Fair and swift peer-review system

Efficient typesetting and proofreading procedure

Display of the result of downloads and visits, as well as the number of cited articles

Maximum dissemination of your research work

Submit your manuscript at: http://papersubmission.scirp.org/ 